\section{A televisão é uma forma de vida}

\section{RESUMO}

Nesta entrevista, Muniz Sodré, um conhecido teórico brasileiro da comunicação, fala sobre a situação do campo de pesquisa de mídia e indústria cultural no Brasil, e apresenta as principais temáticas do seu recente livro Antropológica do espelho.

\section{ABSTRACT \\ In this interview, Muniz Sodré, a well-known Brazilian communication researcher, talks about the state of the art in Brazil of studies on the media and the cultural industry. He also talks about his most recent book Antropológica do espelho. \\ PALAVRAS-CHAVE (KEY-WORDS) \\ - Pesquisa (Research) \\ - Comunicação (Communication) \\ - Mídia (Media)}

UM DOS POUCOS AUTORES que pretende produzir uma reflexão crítico-cultural original sobre a comunicação no Brasil, Muniz Sodré desenvolve importante trabalho nessa linha de pesquisa. É um filósofo e cientista social que trabalha sob uma perspectiva inovadora: a cultura negra em relação à cultura de massa, levando em conta a ideologia.

Autor de 21 livros entre ensaios e ficção, Sodré alterna sua produção teórica com trabalhos sobre mídia e indústria cultural e com ensaios sobre a cultura afro-brasileira. Dos seus livros na área da comunicação, destacam-se A comunicação do grotesco (1971), O monopólio da fala (1977), A verdade seduzida (1983), A máquina de narciso e Claros e escuros (1999).

Nessa entrevista, o autor fala de sua posição teórica diante das teorias de comunicação, como por exemplo a teoria da recepção. Outro aspecto importante salientado por ele diz respeito à temática de o monopólio da fala, a separação radical entre falante e ouvinte. Para quebrar a forma instituída pela mídia, Sodré defende a política de promover a ambivalência no circuito comunicacional.

O autor concedeu essa entrevista por telefone, de sua residência no Rio de Janeiro, em junho deste ano. Ele concluiu há pouco uma obra sobre teoria da comunicação: Antropológica do espelho: uma teoria da comunicação linear e em rede. O livro deve ser publicado até o final do ano, pela editora Vozes.

RF - Como o senhor avalia os estudos em comunicação no Brasil?

Muniz Sodré - A comunicação no Brasil está começando a constituir um campo próprio. Até agora, os estudos em comunicação têm sido muito dependentes de pesquisas estrangeiras. A prova disso 
é que normalmente nos trabalhos que se fazem aqui no Brasil há pouquíssimas citações de autores nacionais. Você pega os trabalhos apresentados na Compós, na Intercom, é muito raro você ter autores brasileiros. E autores latino-americanos quase nenhum. E uma pesquisa de pouco tempo atrás, se não me engano realizada pela Unesco, mostrou que um dos autores de comunicação mais citados no mundo inteiro é o Platão, depois Aristóteles. Mas você nota que um campo amadurece, um campo cresce, quando as citações, as referências, as bases são dadas pela própria língua em que se produz, em que se trabalha. Eu acho que isso pode começar a mudar, porque já se constituiu uma certa massa crítica. $\mathrm{E}$ ao mesmo tempo há uma saturação da forma de reflexão vinda do exterior, da França, dos Estados Unidos. Eu acho que a partir dessa proliferação das escolas de comunicação no Brasil pode surgir uma coisa própria, o que até agora não surgiu.

RF - Em Reinventando a cultura, o senhor faz uma análise sobre as teorias de comunicação no mundo. Gostaria que comentasse a respeito de sua crítica à teoria da recepção, vista pelo senhor como uma pesquisa idealista, onde tudo é comunicação.

Sodré - A pesquisa de recepção foi introduzida pelo grupo dos Estudos culturais. Mas, quarenta anos antes, uma pesquisadora inglesa, chamada Himmelwart, já achava insuficiente as pesquisas de efeito de Stuart Hall, um dos nomes principais daquele grupo. Ela pesquisava com crianças, mas não o que a televisão fazia a elas. E sim o que as crianças faziam com a televisão. Portanto, não é absolutamente nova a teoria da recepção. Apenas ela tem o mérito de mostrar que os efeitos da televisão não são aquilo que a própria televisão pensa. Que há efeitos heterogêneos, diferentes. Quer dizer, os modos de apropriação da mensagem televisiva são diferentes daquilo que a própria televisão pensa. Acontece, no entanto, que esse gênero de pesquisa tem como pressuposto que a televisão é um aparelho transmissor de conteúdos. Ora, em primeiro lugar a televisão não é um veículo transmissor de conteúdos. A televisão é uma ambiência, multissensorial. A televisão não se dirige à mente das pessoas. Ela se dirige ao corpo do indivíduo.

$\mathrm{O}$ jornal se dirige à mente. $\mathrm{A}$ rádio se dirige à mente. A televisão, porém, efetivamente ajuda mais a compor o ambiente, ajuda a fazer o que eu chamo de bios-mediático. Por quê? Porque a televisão cria um ambiente simulativo. Ela cria uma outra realidade e amplia sua própria realidade, onde o indivíduo imerge. Então não é apenas a questão do efeito de conteúdo que está em jogo. O que está em jogo ali é uma administração do tempo do sujeito, administração das consciências, a criação de uma vida vicária, substitutiva. Por isso eu não creio que a metodologia da teoria da recepção, avaliando falas por meio da análise de discurso, dê conta dessa problemática. A teoria da recepção entende a televisão, entende medium como se fosse jornal, rádio. É um entendimento antigo, das décadas de 30 e $40 . \mathrm{Na}$ televisão, porém, não se trata apenas de enunciados de discursos.

$\mathrm{Se}$ trata, sim, de envolvimento multissensorial. Minha crítica então à teoria da recepção é que ela desconhece o fato de que a televisão não é um veículo transmissor de conteúdos. Para estudar a recepção efetiva seria necessário montar métodos, recursos ao mesmo tempo táteis, corporais, para ver o que efetivamente acontece. E, mesmo assim, essa pesquisa me parece muito tautológica. Está colada demais ao próprio poder, à própria hegemonia da televisão. No que isso resulta? Vê se não é a confirmação do mesmo pelo mesmo? Se não é a confirmação do circuito comunicacional? Qual é a utilidade real na verificação dessa recepção? Eu tenho 
minhas dúvidas com relação a isso.

RF - Por isso faz sentido, por exemplo, sua análise sobre a concorrência pedagógica. A questão da publicidade, por exemplo. Ou seja, no espaço social organizado da família, a soberania do pai estaria dividida com a presença da televisão em casa. A criança não teria mais unicamente o pai como rival na disputa pelo sexo da mãe. Ainda é pertinente essa análise?

Sodré - Claro que é muito pertinente. Será que essa forma de vida, bios-mediático, substitui a realidade tradicional? Ou ela amplia a realidade tradicional? Sem dúvida nenhuma, ela é uma ampliação, é uma realidade que se agrega a outra.

Mas a vocação dessa outra realidade ampliada é de concorrer com a realidade tradicional em nome do mercado. Em nome da ressubjetivação das pessoas para torná-las melhores consumidoras, melhores sujeitos adequados ao mercado. Nessa ressubjetivação, nessa concorrência, a televisão assume um lugar de pai e mãe poderosos. Você vê que todas as funções da grande publicidade, das multinacionais, não é para vender coisa nenhuma! Se vende mas é na publicidade de varejo.

Quando uma companhia dessas anuncia petróleo ou gasolina na grande publicidade, notamos que é algo desnecessário para o consumidor. Se você tem carro, não precisa de propaganda para comprar gasolina. Então essa publicidade existe porque é um pouco como a mãe. Baudrillard falou nisso. A mãe passando a mão na cabeça da criança: Olha, meu filho, eu estou aqui com você. Sinta-se seguro. A publicidade tem uma função de envolvimento sensorial, paternalização, de garantir ao sujeito de que alguma coisa no nível macro, no nível do consumo, está velando por ele. E ao mesmo tempo está revelando a onipotência, o poder da empresa. Essa realidade multissensorial é poderosa. Concorre com as figuras que tradicionalmente exerciam poder sobre a consciência do sujeito, que era pai e mãe.

A mídia também concorre sem dúvida nenhuma com a escola. Desde que o homem é homem ele se relaciona com o exterior através de mediações. Cada mediação dessas, a escola, a família, é como se fosse uma esfera com suas regras próprias. A linguagem também, que é a grande mediadora universal. Essas esferas domesticam o homem, deixam o homem em casa. Heidegger, por exemplo, diz que a linguagem é a morada do ser. Cada esfera dessas é uma morada do homem. A mídia, por sua vez, é também uma esfera. Ela não é apenas veículo, porque é uma ambiência. É uma esfera que pretende ser mais envolvente do que as outras. Pretensões de hegemonia, de transformação. A educação é uma esfera que está na base de toda a ética e vice-versa. Não há educação sem ética e nem a ética sem a educação. Nós nos educamos para a ética a partir dos princípios fundadores da sociedade. No entanto, na mídia a ética, os valores, as normas são comerciais. A mídia tem uma moralidade mercantil, moralidade de vendedor, de comerciante.

RF - Qual seria a sua posição nas pesquisas em comunicação?

Sodré - Eu não sou exatamente um pesquisador no sentido clássico da expressão, porque as pesquisas em comunicação são um pouco a pesquisa de campo. Eu sou um ensaísta, que tem a cultura como objeto, tanto em sua forma industrial (a cultura do mass media) quanto a cultura nacional, na forma da cultura negra. A comunicação me interessa primeiro como um campo novo, relativo ao discurso das ciências sociais, e como objeto de reflexão sobre a linguagem e sobre o relacionamento humano. Então me coloco como um ensaísta, debruçado sobre a comunicação e a cultura.

RF - O sistema da televisão é um dos temas que mais dá estudos para trabalhar 
essa problemática da cultura de massa em relação à cultura tradicional. O senhor, inicialmente, partiu de uma análise estrutural do seu código, na década de 70 , para chegar a uma análise que privilegia esse movimento de inclusão e exclusão da cultura negra na dimensão da organização telerrealista. Ao afirmar que a mídia é racista, por exemplo, percebemos o quanto é importante na sua obra a problemática do monopólio da fala. O senhor afirma que o verdadeiro ato político é aquele capaz de quebrar a forma instituída pelo médium. Poderia falar mais um pouco sobre isso?

Sodré - No universo da representação tradicional, a representação ainda tem uma ligação com o referente colocado no real histórico, cujo discurso crítico era voltado para o primeiro plano. Tanto o livro como a imprensa escrita são páreos do pensamento crítico e da razão argumentativa.

Com a chegada do audiovisual, rádio, cinema, televisão, agora a internet, construiu-se um campo onde a representação não é mais do mesmo tipo da representação tradicional, ou seja, do universo da escrita. Agora a representação é apresentativa. Isso significa que o mundo e o seu fluxo estão vinculados e estão como que quase presentes dentro de nossos olhos. A dimensão crítica e a dimensão argumentativa desaparecem, enfraquecem nessa nova constelação da representação apresentativa.

Então já não há mais tantas exigências históricas da crítica quanto havia no passado. Nem a argumentação domina o primeiro plano. Estamos agora no regime daquilo que $E$. Verón chamou de indiciário. A socialização com gestos, nas flexões, nos sinais. Tudo isso que compõe o universo oral e que vem para a mídia eletrônica. No indiciário, não há linearidade discursiva, não há argumentação, não há princípio nem fim.

Há, sim, a estética das aparências. Isso tudo é incompatível com o que nós entendemos como discurso crítico, como argumentação.
A televisão entra aí. Entra nesse regime de visibilidade pública, pontuada pelo indiciário. A televisão é o grande médium indiciário. Ela não precisa, não aposta na argumentação crítica, não aposta nos conteúdos, porque é uma ambiência, é uma forma de interação que como que cobre o social, ou tenta cobrir grande parte do social. A televisão é uma forma de vida própria. Televisão é o suporte técnico, mais o mercado e o capitalismo transnacional. Essa forma é a própria ideologia da televisão. A ideologia não está no que ela diz, não está nos conteúdos, mas nessa forma capitalista mercadológica que os conteúdos assumem. Portanto, o essencial da televisão é a maneira como ela organiza e como se organiza. O essencial dela é o código, a sua própria forma, essa aderência sensorial a que ela convida as pessoas. Ora, sendo portanto prioritariamente forma, sendo sensorialidade, sendo estética, os conteúdos são minimizados, como que exterminados, são liquidados pela pregnância desse envelope, desse invólucro que é a televisão, o que tende a crescer com a internet. Quando McLuhan diz que "o meio é a mensagem", ele quer dizer exatamente isso. Que a mensagem, portanto o conteúdo, está subsumido ao meio, à forma.

O que importa é esse espraiamento sensorial estético da mídia, espraiando a vida da gente, fazendo que a gente habite, more dentro dessa prótese chamada médium. Então o verdadeiro ato político para quebrar essa forma do médium seria o de contrabalançar o poder dessa forma por uma outra forma. Nós, socialmente, vivemos no interior de formas, no interior de esferas mediadoras. Então, quais são as formas da modernidade? A democracia é uma delas. Segundo é a escola. A família monogâmica, nuclear, é outra forma da modernidade. As instituições normalmente são formas mediadoras. Portanto, contrabalançar o poder da mídia é investir na educação, na ética, nas mediações. Gramsci chamava isso de ocidentalização 
da sociedade. Quer dizer, fortalecimento das instituições que constituem a sociedade civil.

Ora, quando a mídia aumenta o poder da sua própria forma sobre as outras formas tradicionais, ela como que provoca, ela desafia a sociedade a responder. Olha, eu sou real. Minha realidade está aqui. Porque a mídia está dizendo o tempo inteiro que a realidade é ela. Então, ela desafia as outras formas, a família, os sindicatos, a escola, as instituições a gritarem sua própria realidade. Portanto, a verdadeira intervenção política na mídia é a intervenção que se faz com uma outra forma forte, que contrabalança o poder dela.

RF - O senhor consideraria a temática de O monopólio da fala de caráter estratégico na sua obra?

Sodré - Apesar da mídia ter mudado muito depois daquele ano em que foi publicado $O$ monopólio da fala, em 1977, eu considero esse livro bastante atual. Porque esse texto não mudou com a interatividade técnica. O monopólio de produção de discurso continua na mão das grandes corporações, das multinacionais. Apenas reabre a possibilidade do sujeito dar uma resposta técnica, através da multiplicidade de canais. Mas é uma resposta nos termos do mercado em que a tecnologia decidem dá pra você. Não é um verdadeiro diálogo. Então eu acho que o texto do monopólio da fala é estratégico sim.

RF - O senhor também não acharia um reducionismo epistemológico privilegiar a temática de o monopólio da fala para estudar a comunicação?

Sodré - Eu acho que a comunicação não é apenas mídia. Quando fiz esse livro, estava preocupado só com mídia. Eu estava pensando apenas um dos aspectos do estudo da comunicação, que é a veiculação mediática. Mas a comunicação, sem dúvida, diz respeito à verdade dos relacionamentos entre os indivíduos. Portanto, do ponto de vista epistemológico, eu realmente reduzi aí o estudo da comunicação com a questão da mídia, da televisão. É uma redução do campo comunicacional, numa atitude de reflexão sobre o anti-humanismo da televisão. O que na verdade sempre está por trás é pensar a humanidade no homem humano, o que significa pensar a riqueza de sua existência. Em Heidegger, é pensar a abertura do ente, do existente, para o ser, das possibilidades que tem de heterogeneidade, diversidade, de exploração da diferença. O que me chamou a atenção naquele momento era a redução da cultura, do espírito público, da experiência humana a essa coisa chamada televisão, chamada mídia. Portanto, eu fui reducionista porque estava na verdade preocupado com o reducionismo que operava sobre a cultura. $E$ acho que não me equivoquei. A televisão na verdade, principalmente a Globo aqui no Brasil, invadiu por inteiro a cultura, com um imenso poder na vida pública. Molda e condiciona campanhas políticas.

Nada disso, depois de vinte anos do lançamento de $\mathrm{O}$ monopólio da fala, mudou. E agora, junta-se a isso a internet, a televisão a cabo. A minha tese do monopólio da fala, do caráter redutor da mídia no espaço cultural, só se vê confirmar.

RF - Em Samba, o dono do corpo, o senhor dá continuidade a essa problemática do monopólio da fala, o que também notamos em livros como $A$ máquina de narciso, $\mathrm{O}$ social irradiado. Mas no Samba, o dono do corpo a gente percebe mais claramente a sua análise a respeito das estratégias de resistência da cultura negra para evitar a transformação ou a destruição da expressão artística. Resistências estas que notamos, por exemplo, nas rodas de samba, na prática ritualística do terreiro. Qual seria então a sua expectativa em relação à sobrevivência destas práticas comunitárias diante dessa forma mediadora 
dominante, que o senhor afirma em sua obra como despolitizante, homogeneizante, tecnonarcisista?

Sodré - Olha, não se trata de sobrevivência. A sobrevivência é de certo modo a idéia do resto, a idéia do moribundo, que continua a viver apesar de sua doença, apesar de ser ferido de morte. Na verdade, a cultura popular, colocada no espaço da cidade, convive com a cultura industrial porque ainda responde a exigências profundas da psique coletiva, que é a exigência da festa. A festa é a maneira como a sociedade, como grupo social, põe em jogo a sua própria identidade. A festa, a mobilização em termo de espetáculo, é a maneira da sociedade ter sua cara no espelho.

O que eu valho, como é que eu significo. A sociedade aí então pode brincar com sua identidade. Pode inverter papéis. Pode, como no carnaval, botar a ordem de cabeça para baixo. A cultura popular responde a exigência de festa com participação do povo. O que acontece é que a mídia, que foi progressivamente assumindo as funções dessa festa, propicia apenas a participação cerebral, apenas visual. As pessoas ficam sentadas, ou em torno da televisão, do rádio, do cinema, da internet.

As pessoas participam sem corpo. É só olho e cérebro. A mesma relação que se tinha com o livro. No livro não tinha festa.

A festa passou para o rádio, cinema e depois para a televisão. Então a exigência popular, mas festa com participação. Portanto eu acho que essas culturas populares, tanto do ponto de vista lúdico como religioso, ainda oferecem oportunidade do corpo integrarse como movimento na festa. O corpo está dentro da festa. Enquanto que a mídia corta o corpo. A mídia é o chamado "corpo sem órgãos”. A mídia é um corpo inerte.

RF - Como surgiu a idéia de trabalhar o mito de narciso relacionando-o ao sistema da televisão?
Sodré - Eu sempre trabalhei muito perto dos psicanalistas. Não só fiz muitos anos de análise, como também sempre dei aulas em institutos de psicanálise, conferências, principalmente com os escritos culturais de Freud.

Isso é uma coisa que não aparece muito nos primeiros livros porque escrevo pouco sobre isso. Mas a verdade é que sou um leitor entusiasmado de Freud. E gosto da psicanálise também, mas como teoria. Só não me agrada o período lacaniano, que é uma encheção de saco gigantesca. Mas Freud é apaixonante. Foi então a partir de minhas leituras psicanalíticas que eu me interessei pela questão do narcisismo.

RF - Na época do lançamento de seu livro A máquina de narciso era uma novidade essa idéia de trabalhar o narcisismo em relação à tevê?

Sodré - Eu tenho a impressão que aqui no Brasil fui eu quem falou isso pela primeira vez. E a idéia não é do narcisismo psicanalítico. Eu não chamo assim. Tratase de um narcisismo secundário, que é reaproveitado pelo estrategista de consumo para fazer um culto ao "eu". Eu havia lido o livro A cultura do narcisismo, de Christopher Lasch. A questão estava nos Estados Unidos.

Depois de eu fazer A máquina de narciso, ele, se não me engano, lançou O mínimo eu. É um livro que aprofunda essa linha, desse "eu" voltado para si mesmo, para alisar a si próprio, que é o "eu narcísico". Só que eu chamei de tecnonarcisismo. Eu Ihe digo que não tirei de ninguém. $O$ próprio Baudrillard não usa essa categoria. Quem está mais próximo disso é mesmo Christopher Lasch.

RF - Na sua opinião, essa proposta foi plenamente trabalhada com sucesso ou ainda sente a necessidade de voltar ao tema? 
Sodré - Eu acho que a televisão, a mídia, é constitutiva de subjetividades novas. $\mathrm{Na}$ verdade, ela altera a própria idéia de subjetividade. Eu sinto que a psicanálise pode ter muito a dizer. Não há dúvida de que eu gostaria de voltar a esse assunto. Nesse meu próximo livro, chamado Antropológica do espelho, que deve sair até o final do ano, tem uma parte sobre a realidade virtual em que sou levado a examinar as alterações no conceito de subjetividade.

Procuro mostrar como a mídia virtual, como a internet, como a rede, vem alterando a idéia de subjetividade humana na função de sua subjetividade mais relacional, ou seja, menos para dentro e mais para fora. Menos reflexiva e mais epidérmica, mais sensorial, que é como as pessoas se dispõem nos contatos de rede mas também nos contatos mediáticos. O sujeito deixa de ser interiorizado para ser mais relacional. Isso eu desenvolvo nesse meu livro A antropológica do espelho, em um dos capítulos.

RF - Então, fale um pouco sobre essa obra?

Sodré - Esse livro resume e amplia minhas posições sobre a mídia até agora. $\mathrm{E}$ ao mesmo tempo tem uma coisa que realmente é muito original. Que é uma teoria da comunicação própria. A teoria do bios-mediático. Eu parto de Aristóteles, da ética de Nicômaco. Aristóteles fala de três bios, que é forma de vida.

A forma de vida do conhecimento, a forma de vida da política e a forma de vida dos prazeres. A esses três bios, três bios que organizam a vida humana na cidade, vida humana sociabilizada, eu me dei conta de que existe um quarto bios hoje, trazido pelo mercado, pelo capitalismo transnacional, que é o bios-virtual, ou biosmediático. Isso significa uma outra esfera da existência, uma outra forma de vida.

Então, um pouco que relativizo, coloco em suspeita todas as aplicações que as ciências sociais faziam até agora sobre a mídia, porque elas tratavam a mídia como se fosse uma realidade no mesmo nível do que as outras. Todos esses estudos da sociologia, da psicologia, da antropologia foram incapazes de revelar a natureza da mídia porque a tratam como se fosse uma realidade ancorada na representação tradicional. Nesse meu livro mostro também a questão dos efeitos. Você não pode ter relação de causa e efeito entre a mídia e a sociedade em que nós vivemos. Porque são realidades, modos de vida de natureza diferente. Não ponto de intersecção direta. Vou então criticar as teorias dos efeitos, inclusive a teoria do agenda setting, pra mostrar como é que esse agendamento se dá. Vou também, a partir daí, mostrar saídas, alternativas, como por exemplo a saída educacional. Mostrar no que a educação difere fundamentalmente da mídia.

Vou mostrar como a mídia é feita de moral. A mídia é uma moralidade. Ao contrário do que se pensa, a mídia não é imoral. Pode ser imoral do ponto de vista do conteúdo. O território da mídia é um território de ethos, de um território de moralidade. Uma moralidade de comerciante, que surge a partir dos costumes, dos hábitos, que é onde a mídia efetivamente se posiciona. A partir daí é que eu vou fazer uma distinção entre discurso educacional e discurso formativo, que é a mídia.

Depois, vou mostrar as alterações que a mídia, com a internet, produz sobre a subjetividade. Vou fazer isso mostrando o que é a realidade virtual. Vou concluir que a mídia é um novo tipo de consciência.

Com a

realidade virtual, é uma consciência que exterioriza, uma consciência maquínica, interiorizada. Pra chegar finalmente a dizer o que é a ética e como é que a mídia poderia se articular com a ética. E expor uma metodologia comunicacional. São cinco partes onde exponho isso. Portanto, eu exponho as bases de uma teoria da 
comunicação.

$R F-E$ qual é a sua expectativa desse seu trabalho?

Sodré - Nenhuma. Eu não espero nada. As pessoas no universo da academia começam a prestar atenção nas coisas que você diz só depois de muito tempo. Você presta atenção imediata ao francês, ao alemão. O brasileiro, ao tentar pensar de modo próprio, dificilmente prestam atenção nele. Você paga um preço ao tentar pensar sozinho. Sou muito isolado.

Mas não me queixo, não. Eu acho que tenho uma relativa notoriedade. Acho que esse livro vai ter que de algum modo circular. Como os outros lentamente circulam nas escolas de comunicação. Eu não faço grande expectativa. É simplesmente uma coisa que eu tinha de fazer. Esse meu livro Antropológica do espelho, sem dúvida nenhuma, é uma posição original. Essa teoria não vem de ninguém.

Com certeza absoluta. Não é nada semelhante a Baudrillard. Espero que pelo menos as pessoas reconheçam isso e discutam. Eu quero que as pessoas critiquem.

Quando eu fiz A máquina de narciso, houve uma crítica na revista do Sebrape, de um cara que hoje não me recordo o nome. Ele fez de dez a doze páginas de crítica muito bem-feitas. Discutiu sociologicamente o conceito de organização. Mas eu não sei mais onde é que tenho isso. Eu espero que quando sair esse livro as pessoas levantem questões, objetem. A teoria progride a partir da crítica.

$\mathrm{RF}$ - E quais foram os autores que tiveram uma influência importante nesse livro Antropológica do espelho?

Sodré - Aristóteles, sem dúvida nenhuma. A ética de Aristóteles. Outro autor é Kant, com a razão prática, fundamentos da metafísica do distúrbio. O resto é leitura instrumental. Mas do ponto de vista de embasamento teórico, foram Aristóteles e Kant.

RF - Nesse sentido, McLuhan também não seria um referencial teórico importante na sua teoria da comunicação? O senhor no seu texto dialoga com ele para fundamentar, por exemplo, seu conceito de televisão. O que vocês têm em comum é o fato de privilegiar o estudo do meio para gerar conhecimento sobre a mídia. Fale um pouco sobre isso.

Sodré - O McLuhan vê os meios de comunicação como extensões tecnológicas do homem. O que acontece é que a televisão tem que ser vista do exterior do movimento da civilização contemporânea para a cibernética.

Eu acho que o McLuhan, embora não mencionasse a palavra cibernética, pensou dentro da cibernética. A cibernética está junto com outra transformação fundamental da sociedade contemporânea que é a biologia. Tanto a cibernética como a biologia, ou a tecnobiologia, se colocam sob o ângulo da teoria dos organismos e da teoria dos sistemas. Então é com a cibernética, a biologia, com a física contemporânea, com aquilo que Hegel chamava de espírito, o espírito objetivo, entendido como a cultura. Mas a cultura feita de artifícios, de máquinas, de artefatos. Esse espírito objetivo se transforma em informação.

O princípio contemporâneo da comunicação resulta de uma transformação do espírito objetivo. Uma transformação da história materializada. Então a informação é uma espécie de valor entre o espírito, que dá a possibilidade de reflexão, e as coisas, os objetos. Você tinha na metafísica clássica espírito e matéria, reflexão e coisa, os objetos.

Você tem contemporaneamen te espírito, informação e matéria. Então as máquinas inteligentes, da mesma maneira que os artefatos da cultura em geral, forçam o pensamento a reconhecer o fato 
de que o espírito, a reflexão, acabou se infiltrando, se colocando nas coisas, nos objetos. Hoje, o pensamento em si mesmo, a consciência, se objetiva nas máquinas, nos objetos. A máquina então não é um simples instrumento.

$\mathrm{N}$ ó $\mathrm{s}$ fazemos as máquinas. Mas as máquinas uma vez ganhando uma autonomia de trabalho com relação ao homem, quando se automatizam, elas passam a colocar problemas, a processar juízos que já não dependem mais tanto do ponto de partida, do output original humano. As máquinas, os meios de comunicação, são memórias ou são reflexões que se objetivaram, que se tornaram objetivadas. Não há um novo tipo aí de ontologia. Com os meios de comunicação o que está em jogo é a possibilidade de consolidação das máquinas, dos instrumentos, como uma realidade própria, objetiva.

Quando se diz que existe a sociedade da informação, você ao mesmo tempo diz que existe uma sociedade governada por sistemas, por memórias fora do homem como culturas ligadas a uma inteligência artificial. E essa objetividade, que está fora da constelação da relação entre homem e mundo, é uma forma envolvente. É isso que eu chamo de bios-virtual, cuja variante é o bios-mediático, e que McLuhan chamava de forma, chamava de meio. Então dizer que o meio é a mensagem é indicar que a questão da mídia está ligada à questão da civilização contemporânea, que é a questão da objetivação do espírito por sistemas, por formas, por máquinas, que em certa medida se autonomizam com relação ao pensamento humano. É nesse ponto aí é que eu acho que a fórmula do McLuhan é uma grande fórmula de pensamento. Em última análise, na informação, os conteúdos, os significados só importam na medida em que se adaptam à forma. Por exemplo: a propaganda de que os Estados Unidos são o melhor país do mundo. Esse tipo de conteúdo só é significativo na medida em que junto com tudo isso vem o mercado, vem uma forma abstrata com relação à realidade concreta das pessoas.

O que importa mesmo é essa forma, esse mundo novo que se cria, essa ambiência, onde nós vivemos no interior de sistemas. Então é preciso entender o meio com isso, com esse envalvointe, o mundo em torno tecnológico, mercadológico. O meio é esse em torno. Não é simplesmente o aparelho de televisão. É esse em torno afinado com o sistema televisivo.

A minha idéia do bios-virtual é essa e sem dúvida nenhuma parte dela está ligada à idéia mcluhiana do meio é a mensagem. McLuhan partiu de pensadores anteriores. Um deles é o padre Teilhart Te Shartin. Tudo que McLuhan disse, o padre Shartin disse melhor antes dele. É o grande pensador da técnica, o grande cosmólogo da técnica antes de McLuhan.

RF - O McLuhan era um otimista em relação a essa tecnologia. Mas o senhor tem outra posição.

Sodré - Minha posição é de um pessimismo ativo. Diferente de um otimismo um pouco delirante, festivo. Eu não espero nada do real tal como se apresenta. Mas também não espero nada do passado. O progresso técnico corresponde ao movimento do modo de produção capitalista e não lamento isso, não. Eu apenas não vejo isso como a chegada do paraíso na Terra.

A mídia é uma compressão das possibilidades de abertura cultural. Mas isso não significa de minha parte nenhuma histeria anti-tecnológica. Essa histeria é reacionária, porque exprime um certo ressentimento da alma, da natureza contra o que o próprio homem produz que é a técnica. Mas existe, é claro, o temor de que a abertura humana se reduza pelo capital em sua expansão ilimitada. E não há dúvida que os instrumentos da comunicação são instrumentos do capital.

Meu pessimismo aparece diante da propaganda que vê isso como voltado para a felicidade, para o bem humano. Eu não acho que se trata disso. Acho que isso 
apenas acompanha a lógica do movimento do modo de produção capitalista. Eu não espero nada, mas ao mesmo tempo eu acompanho ativamente esse movimento capitalista.

RF - A exemplo de Renato Ortiz, entre outros, poderíamos afirmar que o senhor é um autor que também produz conhecimento original?

Sodré - Não poderia fazer um juízo desses sobre mim mesmo. Só os outros podem afirmar. Sem dúvida nenhuma, eu tento incluir a forma negra de pensar e a forma popular de pensar na minha reflexão acadêmica, erudita. Eu vejo o eruditismo do povo. $\mathrm{Na}$ arte popular há também a presença do erudito, a presença do complexo e há também pensamento. Esse pensamento pode estar na canção do Lupicínio, no samba de Noel, na composição de Caetano Veloso, Chico Buarque. Pode também estar no maracatu, no futebol.

O pensamento para mim não é o exercício da pura razão argumentativa em bases acadêmicas. O pensamento da verdade é um fazer-mundo. É fazer o mundo acontecer. É deixar que as coisas aconteçam. Esse deixar que as coisas aconteçam é estar no mundo. É fazer-mundo. Para mim, então, todo o pensamento com interesse filosófico é um pensamento vira-mundo.

Ou seja, ele quer produzir acontecimento, que é um rompimento do que está dado. Um acontecimento que avança rompendo coisas. Você avança no mundo como um vira-mundo. Minha maneira de pensar é uma maneira viradora. Não consigo sempre isso. Eu não sou stricto sensu antropólogo nem sociólogo, mas o que se chamava antigamente de livre pensador. Só que estou comprometido a pensar a comunicação, a cultura. Então eu aproveito os materiais que me caem à mão, que me parecem ajudar o pensamento. É exatamente assim um pouco que eu trabalho. Eu faço leitura mais sistemática de filosofia, que gosto muito. $\quad \mathrm{Na}$ verdade, minha grande inspiração sempre foi Nietzsche. Tem duas metáforas dele que gosto muito. É a questão do pensar como uma vaca ruminando. Eu também gosto de ruminar as coisas. E depois a questão do faro. Eu sou capaz de sentir cheiros a distância. Tenho fenômenos estranhos com cheiro. Deve ser minha ascendência indígena. Mas esse meu faro não é apenas físico. Farejo coisas. Nietzsche diz assim: eu sou o primeiro que sentiu a mentira como mentirosa. Nos meus ensaios, isso que você chamou de originalidade é coisa que eu farejei. Quando estou fazendo um trabalho, os autores vão me caindo na mão quase que por acaso. Parece que Exu bota.

Às vezes a idéia não é exclusivamente minha, mas procuro uma maneira singular de abordá-la. Eu parto dos outros, mas eu gosto também de ter as minhas idéias. Se alguém já falou muito daquela maneira, eu saio de baixo. Eu sou assim. Não é porque esteja querendo ser original. Mas eu não vou repetir argumentos demais. Para mim, o método é o caminho depois que você passou por ele. Pearce diz que você tem que inventar. Ele chama isso de abdução.

Depois que você cria e acha o caminho, daí você fala com mais segurança de seu próprio método. Mas se o método é um caminho prévio, que os outros dão para você, você vai apenas fazer coisa que a academia reconhece como pertinente, mas que não revela nada, não descobre nada. E a função das ciências sociais é iluminar, revelar, esclarecer para poder ter a crítica e o debate. Não tenho nenhuma pretensão de originalidade absoluta, porque eu leio os franceses e aproveito coisas dos franceses. Leio os alemães, aproveito também. Leio os italianos e aproveito. E, quando é possível, aplico esse conhecimento à vida nacional. Se eu tiver alguma originalidade, a originalidade é essa. Eu penso como um crioulo de terreiro, como um negro nagô, mas com a linguagem, o jargão acadêmico. 
RF - A sua relação do poder panóptico de Foucault com a televisão, em $\mathrm{O}$ monopólio da fala, foi, sem dúvida, uma análise original, uma das pioneiras na academia.

Sodré - Naquela época, quando foi publicado o livro, em 1977, era sim uma novidade. A televisão é um panóptico invertido. Não é o guarda, no centro, olhando para os prisioneiros. É o contrário. É eu que fico olhando para alguém. O controlado é quem olha. O panóptico aí se inverte.

Eu estava na verdade movido pela idéia de Foucault, o panóptico disciplinar. Mas aplicando isso à televisão, damos conta da inversão. Nada é nunca absolutamente novo. A gente sempre está partindo de uma idéia, que é reinterpretada e acrescida com outras leituras.

RF - Como surgiu essa questão da cultura negra na sua obra?

Sodré - Eu tenho antecedência de índio por parte de mãe e da parte de pai é de negros. Vivencio diversos terreiros e pude ver o que estava se passando ali dentro. Eu pertenço efetivamente àquele universo. Então eu procuro forjar minhas categorias, pensar a partir de dentro desse universo, cujas pessoas na sua maioria não tiveram educação formal no sentido de produzir esse discurso acadêmico.

Eu sou aba-xangô. Aba significa alguém que representa o terreiro em termos de discurso. Essa é minha função. Vou te dar um exemplo. Um tema que me interessa é o da alegria. Como podemos ser alegres? $O$ que é isso? $O$ que é a lacridade. Experimentá-la sem ter que necessariamente pagar preços monetários por ela. Esse gozo com a vida em si mesmo, a partir da dimensão simbólica, isso me interessa. $O$ meu interesse pela cultura negra, pelo terreiro, é que eu vejo nessa cultura a possibilidade de pensar coisas dessa ordem. Pensar a alegria de estar vivo. Pensar também a questão da violência, da catástrofe, da inveja do outro, da crueldade, da perversidade, questões que estamos cercados por elas o tempo todo.

Eu acho que a civilização ocidental cristã lida mal com todos esses aspectos. A psicanálise, por exemplo, tenta lidar, mas tenta recuperar isso para a racionalidade e não consegue. Eu gosto de psicanálise. Fiz análise muito tempo. Respeito muito ainda hoje a teoria psicanalítica. Desconfio um pouco é da prática.

RF - Em A verdade seduzida, por exemplo, Heidegger foi um suporte teórico para falar sobre ser e aparente. O senhor vê aí a importância da cultura das aparências no processo de troca simbólica, onde falante e ouvinte não estão separados por uma instrumentalização do real. Heidegger, aí, coincide ou não com a forma negra de pensar? Ele teria ajudado você a trabalhar com a forma de pensar do negro? Fale um pouco dos aspectos da cultura ocidental que convergem com a forma negra de pensar.

SODRÉ - Eu acho que dentro da cultura ocidental tem momentos de se pensar igual ao negro. Por exemplo: Schopenhauer, Spinoza. E Heidegger é o grande filósofo. Em Heidegger tem a questão da crítica, entendida como observação, como distinção, como discernimento. Ele é um filósofo que dá atenção à terra. Diferença entre terra e mundo. É um filósofo que mostra a presença dos deuses, a presença do transcendente. E ao mesmo tempo é um filósofo que mostra também a importância do tempo.

É na verdade um filósofo da temporalidade e que oferece para a questão do negro no Brasil a possibilidade de pensar na outra transmissão temporal para além da história, que é a ancestralidade. Nisso, há algo em comum entre Heidegger e a cultura negra: a questão da ancestralidade, que é muita 
próxima da concepção de ancestralidade dos nagôs.

Quer dizer, as vozes que partem do passado em que a história de hoje as responde. Essa voz, para o negro, é como um destino. Ele está constantemente respondendo as mensagens do passado. Há muitos pontos em contato entre Heidegger e a cultura brasileira e é por isso que ele me interessa muito. Mas Heidegger exclui a dimensão da luta, que é muito forte em Nietzsche e que é muito forte entre os negros.

Nietzsche diz assim: fulano é educado demais para lutar. O negro africano, nagô, de terreiro, vê como luta a própria relação amorosa. Ele vê o sexo masculino e feminino como princípios de luta, princípios complementares em luta. Então a luta é também fazer compreender com ações. Isso é muito próprio do negro e isso está em Nietzsche.

RF - Na década de 70, o senhor trabalhou em parte com o pensamento do estruturalismo, mas ressaltando que esse método não esgota o conhecimento da cultura. Até que ponto o pensamento estruturalista foi útil para o seu trabalho?

Sodré - Eu fui realmente um grande conhecedor e amante do estruturalismo. Eu acho que o estruturalismo de LevyStrauss, de Barthes, de Lacan, toda essa gente, cada um com seu modo de se dizer estruturalista, chamou a atenção para o que efetivamente me interessa muito, que é a linguagem. A grande descoberta do estruturalismo foi o papel central da linguagem na constituição do sujeito. Ajudou a tirar da cabeça dos acadêmicos a idéia de que a linguagem é um simples veículo e a colocou em primeiro plano, como aquela instância agenciadora que constitui o sujeito, que constitui a vida social e que nós vivemos na linguagem a partir da linguagem. Para mim, essa foi a importância do estruturalismo.

RF - Percebemos na sua obra a preocupação em analisar a natureza do código da cultura de massa. O código já foi chamado de retórico-globalizante, de modelo, de campo e, neste último livro, que trata de uma teoria de comunicação, o código é denominado de bios-mediático. Fale um pouco sobre isso.

Sodré - O bios é o código. É a codificação que se faz vida. É como se fosse uma membrana que envolvesse os indivíduos. Isso é o bios. E os indivíduos passam a circular, a se movimentar a partir das regras do código. Só que eu não uso mais a palavra código. Eu peguei a palavra aristotélica bios. No lugar de dizer o código virtual, eu digo o bios-virtual. É pra indicar bem que se trata de uma ambiência, de uma forma de vida e não de uma operação semiótica manobrada por alguém.

RF - Notamos na sua obra a influência da teoria crítica da Escola de Frankfurt, principalmente na década de 70 . O senhor faz algumas objeções a ela. Fale um pouco sobre isso.

Sodré - Sem dúvida nenhuma, a Escola de Frankfurt, de Adorno e Horkheimer, foi a que mais percebeu antecipadamente o que estava por trás da intervenção da técnica na cultura contemporânea. Mas Adorno e Horkheimer eram muito nostálgicos da cultura elevada. Eu acho que eles não pensaram é que o pensamento crítico depende de um distanciamento entre sujeito e objeto. E é próprio desse biosvirtual uma redução, senão o acabamento, dessa dicotomia própria da metafísica entre sujeito e objeto.

E $m$

Adorno e Horkheimer, no pensamento crítico clássico, ainda é um pensamento da metafísica, uma montagem universal de significações, que procede por divisões rígidas entre sujeito e objeto, entre natureza e cultura. Adorno ainda é tributário dessa divisão, dessa metafísica clássica, que repousava, ao mesmo tempo, sob o laço entre a ontologia monovalente e uma lógica 
bivalente das coisas: $O$ verdadeiro não é falso, o falso não é verdadeiro. Não existe aí um terceiro termo. Uma lógica de junção ou conjunção. Ou é ou não é. Essa lógica bivalente das coisas é uma lógica que não dá conta dos fenômenos culturais, como por exemplo os signos e os instrumentos da indústria cultural. Que não permite também uma boa análise das obras de arte e nem das transformações dos costumes. Então essa divisão fundamental entre alma e coisa, espírito e matéria, sujeito e objeto, a máquina e a liberdade do homem, deixa de lado a realidade onde há um terceiro dado, que é o terceiro excluído. Adorno e Horkheimer e a teoria crítica clássica dependiam dessa ontologia monovalente e dessa lógica bivalente. Adorno está do lado da alma. As coisas são dominadoras, alienantes. E quando se coloca com o olhar da cultura elevada, ele responsabiliza as coisas pela dominação que exercem sobre o homem e é a partir daí que constitui a sua teoria.

RF - É por isso que Adorno e Horkheimer não admitiam, por exemplo, que a cultura popular também produzisse conhecimento, produzisse arte.

Sodré - Não admitiam porque no fundo a cultura popular estava do lado da coisa, dos objetos. Eles eram platônicos, no sentido de que a idéia universal é que é propriamente o ente, enquanto que a matéria, o objeto, não constitui o ser. É uma espécie de não-ser.

Ora, as culturas populares estavam dentro dessa teoria crítica do lado do nãoser. Quando, portanto, a matéria passa a ser substancializada, as idéias da cultura popular são também consideradas como não-verdadeiras, como não-sendo. É, portanto, uma teoria crítica aristocrática. Está ligada ao programa metafísico platônico-aristotélico.

RF - Professor, e a semiótica? Até que ponto ela influenciou a sua obra?
Sodré - Eu gosto da semiótica. Fui aluno de Barthes. Para mim, ele foi o mais criativo em praticar a semiótica. E praticar inventando. Mostrava o método, mas dizia ao mesmo tempo que esse método era uma invenção dele. O reaproveitamento de Saussure. Eu sempre gostei, me encantei com a semiótica. $E$ eu cheguei à comunicação por via da teoria da linguagem, porque sempre fui voltado para a questão da linguagem. Primeiro pelo meu interesse por língua. Eu aprendi sozinho. Nunca tomei curso, a não ser o alemão. Desde menino, eu falo inglês, francês, alemão, russo, italiano, espanhol. Recentemente, estudo árabe. Fui professor de latim. Falo iurubá, que é a língua dos terreiros, um pouco do crioulo de Cabo Verde.

Enfim, sou muito afeito a línguas estrangeiras. Hoje menos, mas era muito mais. Foi então pelo interesse pela língua que me interessei por lingüística. $E$ da lingüística passei para a semiótica. Mas não dou mais aula disso. Particularmente, não me interessa mais como um método para estudo. Não confio mais nos resultados metodológicos da análise de discurso. Eu acho que é a reflexão o caminho. Mas eu gosto particularmente da semiótica de Peirce. E tem gente que faz coisas criativas com a semiótica de Peirce. Cito por exemplo um uruguaio, que é muito amigo meu, chamado Fernando Antarsht.

Mas a tendência é sempre repetir um pouco o que Pearce fez. Então, o que eu noto é que a semiótica, assim como a análise de discurso, é muito um fascínio como método dos outros, é muito a repetição metodológica.

RF - Um conceito que nos parece importante na sua obra é o de mito e nesse sentido Barthes é um autor com influência decisiva, principalmente ao trabalhar a questão da identidade, não é mesmo?

Sodré - Esse conceito me foi dado com o estruturalismo, principalmente 
com Barthes. O seu livro Mitologias me impressionou muito. Não só pela maneira como ele escrevia aqueles textos, mas também pelos caminhos metodológicos que ele indicava, mostrando como o mito era uma palavra evasiva. Não era mais o mito das sociedades tradicionais. Mas um mito empurrado pela ideologia. $\mathrm{O}$ mito de Barthes era mais uma mitologização do que um mito original. A maneira como a eternização da ideologia invadia as figuras da cultura burguesa pra convencer as pessoas da eternidade das significações burguesas. Só que isto era muito provisório em Barthes. Quando ele fala de mitos, ainda havia a consciência desmistificada, a consciência esclarecida e momentos mitificantes da cultura burguesa. O problema é que com a extensão da cultura de massa tudo tende a ser ressignificado, mitologizado no espaço público.

Então essa categoria perdeu a importância pra mim com a expansão da cultura industrial. Mas eu passei a valorizar a questão do mito doutra maneira. Ou seja, ver a verdade nos mitos originários, ligados às grandes cosmogonias na cultura negra. O candomblé e o culto afro são sistemas que vivem o mito. Mas não é esse mito ideológico, de ressignificação. É um mito de revelação originária do real. Não é um mito a ser desmistificado, combatido. Mas é um mito a ser compreendido. Vem daí. Vem do estruturalismo e da minha vivência na cultura negra.

RF - E Barthes parece mesmo ter uma influência decisiva no seu texto quando ele trata sobre a "negação do outro", dos modelos de reconstrução mítica da identidade. Isso é importante na sua obra e está sendo cada vez mais, não é?

Sodré - Cada vez mais. Porque essa questão tem uma contrapartida política. Eu não vejo as ciências sociais no interior do jogo político. Não é que as ciências sociais vão ser doutrinárias, partidárias. Não é isso. Elas só se justificam na medida em que são capazes de responder, de atuar dentro da práxis e constituição da subjetividade e da identidade humana.

Então, as ciências da comunicação, a teoria da comunicação, interessam na medida em que eu posso fazer uma crítica dos aparatos de poder, dos aparelhos de dominação, que estão colocados aí pelo mercado, pelo capital transnacional. Para isso, eu tenho que ver quais são os pontos de exercício desse poder. E o ponto básico é a questão da identidade subjetiva.

RF - Então fale um pouco sobre a singularidade em relação à identidade. A questão da perda de si no outro, a importância da atitude ética para aproximação das diferenças, o que implica singularidade ativa e não receptor passivo.

Sodré - A singularidade é um conceito que se opõe ao de identidade. A identidade depende de comparações. O grande poder cultural e simbólico do Ocidente é o poder de comparar. Em toda a comparação você tem uma operação forte de poder.

Porque quem sobrevive à comparação é o comparador. É aquele que dá o termo comparante. Quem é que tem o poder de fazer a comparação? Daí dizem que todos os homens são iguais. Mas nessa frase quem diz que os homens são iguais é mais poderoso do que os outros, porque é ele quem faz essa comparação. Mas nós sabemos que todos os homens são diferentes. E não só pela cor, mas de cabeça. Seu pai é diferente de sua mãe, de seu irmão, diferente de mim. E ao mesmo tempo semelhante, já que é pessoa. Não somos iguais nem desiguais. Somos simplesmente pessoas diferentes que coexistem no espaço.

Então por que comparar? Falar no mais forte, no mais sábio? No mais igual, no menos igual? Então a identidade é - lugar de poder sobre a consciência, sobre a subjetividade. Já a singularidade não precisa de comparação, pois ela é a aceitação do outro tal e qual ele se apresenta no seu movimento, em sua ação. 
Um exemplo nesse sentido pode ser em relação a sua mãe, a sua namorada. A sua alegria interfere no outro. No fundo você gosta de sua mãe pela alegria que você tem em relação a ela. Isso significa que ela é tal e qual como se apresenta. Com os defeitos, as virtudes, é feia, bonita, velha, nova, viva ou morta.

Você não a compara com a mãe de seu amigo. Essa aqui é a minha mãe. Você não a ama pela sua identidade, mas pela sua singularidade, pela sua incomparabilidade em relação a você. É nessa ambivalência que você cresce e que ela também se afirma como sua mãe. Ambivalência é luta. É a possibilidade das coisas já identificadas mudarem um pouco de lugar.

RF - O senhor dialoga com diversos autores para fundamentar seu trabalho de pesquisa em comunicação. Baudrillard, Foucault e Christhopher Lasch, por exemplo, teriam uma influência decisiva em algumas reflexões. Estou certo? Quais seriam os outros?

Sodré - Baudrillard, por exemplo, foi para mim uma descoberta. Acho que é um pensador que não tem discípulos no sentido de que ele tem a sua versão, o seu chute. Ele chuta muito. Criativo e chutador.

Daquela

forma e com aquele exagero, é uma jogada dele. Ele é um criador radical. Então é possível pegar o que ele diz e fazer daquilo um conceito para trabalhar. Porque ele mesmo nos autoriza isso. $\mathrm{E}$ pensamento é criação, chute e suor. Desse modo, ele teve, sim, uma influência importante no meu texto. Eu sempre fui leitor de Marx, que sugere recriação, me ensina a recriar. E também fui leitor de Freud. E Baudrillard é alguém que passeava por esses autores, inventando, criando. Barthes também me influenciou bastante. Ele foi meu professor em Paris, a exemplo de Baudrillard, que é meu amigo até hoje. As grandes influências são Barthes e Baudrillard, sem dúvida nenhuma.
RF - O senhor se considera um pensador de esquerda. Seria por causa disso que sua obra não faz uma abordagem culturalista, pois leva em conta a ideologia? Suas críticas a Gilberto Freyre, por exemplo, atestam essa perspectiva teórica.

Sodré - Por trás ou junto com todo o repertório cultural, de todo o enunciado culturalista, tem um enunciado político. Mesmo que a política representativa esteja em crise no Ocidente, o homem é um animal político. As formas de socialização são formas políticas. A política não é só uma questão partidária, a política dos cientistas políticos. Política é esse movimento de organização das formas de vida, de relacionamento com o Estado, de relacionamento dos assujeitados com o poder. Portanto, eu acho que não é possível encarar a comunicação apenas a partir dela mesma. Partir desse movimento produtor disso que nós chamamos cultura. A comunicação tem que ser pensada a partir de fora. Nós podemos estar dentro dela, mas tem um determinado momento em que é preciso olhar ela de fora para poder ter um juízo crítico. E essa olhada de fora, essa decisão de criticar, é uma decisão política. Para mim, a ciência da comunicação é um estudo com interesse político e científico. Desse modo, sem dúvida nenhuma, minha abordagem não é culturalista.

RF - Em A verdade seduzida, o senhor afirma que a cultura de massa é um subcampo da cultura burguesa. Isso, por exemplo, diverge do pensamento da Teoria Crítica. Essa sua posição parece ser bem coerente com seu pensamento, que valoriza a cultura negra no sentido dela ser também capaz de produzir conhecimento. Ou seja, o senhor faz questão de salientar que a cultura negra é singular em relação à cultura de massa. Já o mesmo não se poderia dizer em relação à cultura burguesa. Seria isso? 
Sodré - Essa reflexão é de 1983 e de lá para cá as coisas mudaram muito. Naquele momento, sem dúvida nenhuma, a cultura de massa era um subcampo da cultura burguesa. Um momento em que a cultura de massa era muito ameaçadora e era uma novidade. Neste momento, com a realidade virtual, esse subcampo se confunde com o campo da cultura burguesa. Já não há uma distinção tão grande entre cultura burguesa e cultura de massa. Na rede, como na internet, a cultura dita "elevada", ou a cultura complexa, pode conviver ciberneticamente com a trivialidade. Então, essa distinção cultura elevada/cultura de massa deixou de ter a mesma relevância que tinha vinte anos atrás. Por isso, hoje não se tem um grande interesse teórico em fazer essa distinção entre campo e subcampo.

RF - Essa idéia de campo e subcampo o senhor se valeu da metodologia de Pierre Bourdieu. Até que ponto ele foi útil para essa reflexão?

Sodré - O Bourdieu para mim é um ser jurássico. Ele faz aqueles grandes sistemas e que me lembra um pouco aqueles pintores holandeses do século XVIII. Um fazia o rosto, outro a roupa e no final o mestre assinava o quadro que era vendido na grande sala burguesa. $O$ Bourdieu me lembra muito isso. É a figura mais importante da sociologia francesa. Produz aqueles grandes livros, com muitos pesquisadores, e no final ele assina. Faz aquelas explicações detalhadas dos aspectos da cultura, mas ninguém consegue ler por inteiro. São livros muito tautológicos. Mas sem dúvida nenhuma, principalmente o Bourdieu da primeira fase, ele tem momentos importantes na sociologia.

O Bourdieu da antropologia prática, o Bourdieu da violência simbólica. Essa história dos campos me serviu metodologic amente.
RF - Em Reinventando a cultura, o senhor realmente abandona essa dicotomia cultura elevada/cultura de massa. Quando, por exemplo, sua análise se detém à obra de arte, notamos a problemática a respeito dela, seja da cultura burguesa ou da cultura popular, gerar demandas fora da sistematização do valor de troca da cultura de massa.

Sodré - Isso vale para qualquer obra que queira se reconhecer ou não como arte. $\mathrm{E}$ a palavra arte é cada vez mais complicada.

Eu acho que a obra de arte, como saída do valor centrado no capital, é ao mesmo tempo buscar no social qual é a potência mais alta do homem. O que no homem fica como potência maior para além do preço do mercado. Como é que o homem pode ter experiência de plenitude a partir de sua própria autonomia. Como é que ele pode celebrar os aspectos efêmeros da vida dele, ver a eternidade na plenitude dele, gozar incondicionalme nte a vida sem as cauções de preço, do mercado, do valor.

RF - Nesse sentido, vale destacar a sua análise no campo da literatura. Gostaríamos que o senhor comentasse um dos aspectos focalizados na sua obra: o conceito de subjetividade, que entre outras coisas serve para ressaltar como é trabalhada a questão identitária na literatura de massa, na elevada e na popular. Exemplo: a desvalorização de negros e índios na literatura de José de Alencar e Monteiro Lobato.

Sodré - Para mim o romance foi a forma popular encontrada pelo Ocidente para afirmar na história o sujeito da consciência. O conceito de subjetividade depende das narrativas que a sociedade elabora sobre o que é esse sujeito autônomo, consciente e separado do objeto. Portanto, há subjetividade na medida em que há narrativas sobre a subjetividade. Essas narrativas são a filosofia platônica, 
que é reaproveitada pela narrativa do cristianismo. É o romance, a poesia. É a difusão dos retratos da modernidade. São todos os grandes textos que se referem ao homem como uma subjetividade autônoma, isolada. Portanto, a literatura do Ocidente, principalmente a narrativa romanesca, é uma literatura voltada pra consolidação da subjetividade, de uma subjetividade com uma vida interior a ser sondada pelos poetas, pelos analistas da alma, pelos psicanalistas. A literatura do Ocidente, então, é uma literatura demonstrativa da constituição do sujeito, feita por sujeitos eventualmente geniais. É uma exaltação da grande subjetividade. Ora, isso não ocorre na cultura negra, nas culturas tradicionais, porque o que está posto no primeiro plano é o grupo, a coletividade. É a subjetividade grupal, e não é a mesma coisa da subjetividade individual. Nesse meu livro A teoria da literatura de massa eu mostro a diferença entre a literatura de consumo e a literatura de grande alcance simbólico, tendo no meio como diferenciadores os aparelhos de reprodução dos efeitos, que no caso da grande literatura é a escola. E mostrar que no caso de outras literaturas, de outros discursos, há instrumentos materiais de reprodução dos efeitos que não estão necessariamente ligados à subjetividade. Por exemplo: a literatura dos escritos negros e também a literatura de grande consumo, onde também não é tanto a subjetividade do autor que é valorizada, mas a subjetividade dos personagens. São técnicas também de produção de subjetividade, mas a partir dos conteúdos.

RF - Um aspecto da subjetividade que o senhor salienta e que está presente tanto na literatura de massa como na televisão diz respeito ao seu caráter pedagógico para a constituição do sujeito.

Sodré - A televisão, assim como a literatura de massa, é pedagógica. Aí há um ponto em comum, sem dúvida nenhuma. E cada vez mais nós estamos vivendo um pedagogismo público. Um pedagogismo popular, que tenta o tempo inteiro ensinar coisas às pessoas. Já não vê mais desint eressadamente animais na televisão. Você tem que saber como é que aqueles animais se reproduzem, vivem. Não há mais uma contemplação distraída, desinteressada.

RF - Com a realidade virtual já teríamos outro tipo de análise em relação à subjetividade.

Sodré - Os conteúdos da literatura de massa são da ordem do imaginário, da ordem da fabulação mítica. Ao mesmo tempo, da ordem de uma pedagogia da constituição do sujeito. Enquanto que na realidade virtual, eu acho que ela supera a questão do imaginário. A realidade virtual é esse imaginário feito realidade. Já não se trata mais de um lado o real e do outro o imaginário, como é no caso da literatura de massa. Então na realidade virtual o imaginário se substancializa. Você entra nele, você vive ele. Você já não sabe mais o que é real e o que é imaginário. $O$ que está em questão aí é exatamente a indistinção entre real e imaginário.

RF - Notamos em seu texto, entre outros aspectos, três linhas de força para o estudo da cultura de massa: a questão do poder, da subjetividade e da identidade. A identidade, por exemplo, o senhor trabalha em toda a obra. Notamos isso, por exemplo, quando trata da conversão de falante/ouvinte para emissor/receptor. Nessa conversão já teríamos, de modo implícito, a problemática da identidade: ou se é produtor ou se é consumidor. Ou seja, o sujeito não tem experiência existencial com o código. Já em Claros e escuros, o senhor estuda a identidade explicitamente: a identidade cultural brasileira. Como se dá a evolução de seu pensamento sobre a identidade no seu texto?

Sodré - Essa questão da identidade que estava no receptor, ou se é produtor ou se é consumidor, eu mesmo não havia 
percebido isso dessa forma ... Mas o que você está dizendo faz sentido. Isso é luta, entendeu?

E luta significa

a possibilidade de os termos polares de uma relação terem valências diferentes no relacionamento. E na mídia, você não tem peso diferente. A mídia está ali, estática e imóvel, falando com você. Agora, eu me dou conta do seguinte: que a intelectualidade brasileira sempre teve de forte o pensamento sobre a identidade. A identidade foi o campo de onde poderia ter nascido a filosofia brasileira. Foi aí nesse campo onde despontou gente como Afonso Arinos, Gilberto Freyre, Sérgio Buarque de Holanda, Caio Prado Júnior, Capistrano de Abreu. Foram autores que tentaram explicar a identidade nacional. E a partir daí produziram obras reveladoras sobre - Brasil, com perspectivas sociológicas, antropológicas, históricas, psicológicas.

Mas eram obras que misturavam essas disciplinas. Não se limitavam a uma única perspectiva teórica, o que resultava numa quase filosofia. Não era filosofia porque as questões não tinham unidade na constituição e nem no campo do pensamento. Era um ensaio. A questão da identidade nacional sempre me interessou. Me interessou do ponto de vista do negro, que não responde a essa questão da identidade nacional reflexivamente pela escrita, mas responde pela ação, pela liturgia, pela festa, pelo sagrado, que é outro modo de responder. Respondeu com o corpo. Não respondeu com a cabeça. E o corpo é um outro tipo de pensamento. A corporalidade tem uma lógica própria de pensar. E tudo isso parte da questão da identidade. Mas pensando agora no que você diz, retrospectivamente, eu vejo que a questão ... falante, ouvinte, é também uma questão da mudança da identidade no sujeito ... Cabe a você falar nisso .

Nota 